https://doi.org/10.18485/iipe_postkovid.2021.ch17

\title{
KLUČNI IZAZOVI NOVE METODOLOGIJE PREGOVORA O ČLANSTVU U EVROPSKOJ UNIJI U KONTEKSTU PANDEMIJE SARS KOV-2
}

\begin{abstract}
Nenad A. VASIĆ ${ }^{1}$
Apstrakt: Zvaničnici Evropske komisije, posle sastanka kolegijuma komesara održanog 5. februara 2020. godine, usvojili su i predstavili novu metodologiju pregovora o članstvu u EU za države Zapadnog Balkana. Kao revidirani proces pristupanja nova metodologija pregovora direktno će se primenjivati na Republiku Severnu Makedoniju i Republiku Albaniju. Nakon što je Republici Srbiji i Republici Crnoj Gori ostavljena mogućnost izjašnjavanja o usvajanju nove metodologije, zvaničnici dveju država odlučili su da prihvate revidirani pristup pregovora o pristupanju Evropskoj uniji. Ovakva odluka tek treba da pokaže svoje efekte, kako u odnosu na građane tako u odnosu na predstavnike elita na vlasti u državama kandidatima za članstvo. Očekivani rezultati se odnose najpre na domen stabilnosti, vladavine prava, demokratičnosti političkih sistema, ljudskih prava i sloboda, ali i ekonomski razvoj i socijalno blagostanje. Najveći aktuelni izazov za uspešnu implementaciju nove metodologije Evropske unije, nesumnjivo je donela pandemija SARS KOV-2. U okviru zdravstvenog izazova uslovljenog izbijanjem pandemije, identifikovani su i ostali politički i ekonomski izazovi, kako za države članice tako za države kandidate za članstvo u EU, među kojima se izdvajaju, pitanje uspostavljanja cirkularne ekonomije, dosezanje proklamovanih ciljeva Evropskog zelenog plana, kao i nerešeno pitanje statusa Kosova u okviru pregovora o pristupanju i članstvu Republike Srbije i drugi.

$U$ radu se analiziraju mogućnosti i perspektive za primenu nove metodologije pregovora u uslovima pandemije SARS COV-2, i potencijalni uticaj pandemije na
\end{abstract}

\footnotetext{
${ }^{1}$ Naučni saradnik, Institut za međunarodnu politiku i privredu, Beograd. E-mail: nenad.v@diplomacy.bg.ac.rs.

Rad je nastao u okviru naučnoistraživačkog projekta „Srbija i izazovi u međunarodnim odnosima 2021. godine“" koji finansira Ministarstvo prosvete, nauke i tehnološkog razvoja Republike Srbije, a realizuje Institut za međunarodnu politiku i privredu tokom 2021. godine.
} 
pregovorački proces Republike Srbije. S druge strane, i sama Evropska unija kao sui generis međunarodna organizacija, koja uživa međunarodnopravni subjektivitet, suočena je sa potrebom unutrašnje reforme. Najava udruženog povratka Evropske unije sa Sjedinjenim Američkim Državama (SAD) na Zapadni Balkan, bez dileme će usloviti preispitivanje i prilagođavanje spoljne politike Vlade Republike Srbije novim međunarodnim izazovima, ali i bilateralnim i multilateralnim okolnostima relevantnih aktera.

Ključne reči: Evropska unija, Republika Srbija, Zapadni Balkan, pandemija SARS KOV2, nova metodologija, pristupanje

\section{Uvod}

Sadašnja Evropska unija je međunarodna organizacija sui generis sa 27 punopravnih država članica. ${ }^{2} U$ savremenim međunarodnim odnosima Evropska unija uživa međunarodnopravni subjektivitet. ${ }^{3}$ Od pojave korona virusa najpre u Narodnoj Republici Kini, u provinciji Hubej i gradu Vuhanu krajem 2019. godine, a kasnije i proglašenja prve pandemije od strane generalnog direktora Svetske zdravstvene organizacije (SZO), Tedrosa Adanoma Gebrajesusa, 11. marta 2020. godine, na testu su zdravstveni sistemi svih država članica kako Evropske unije tako i Ujedinjenih nacija. ${ }^{4}$ Pandemija SARS KOV-2 stavila je u fokus zdravstvenih sistema pitanje adekvatnog lečenja po propisanom protokolu u zdravstvenim ustanovama, uključujući i adekvatne mere prevencije poput poštovanja mera propisanih od strane zdravstvenih stručnjaka, kao i medicinskih protokola lečenja obolelih od virusa.

Pandemija SARS KOV-2 u svim aspektima i izazovima od samog izbijanja, nesumljivo postaje tema interesovanja intelektualne i naučno-stručne javnosti u

\footnotetext{
2 Jonathan Olsen, John McCormick, The European Union: Politics and Policies, Westview Press, Boulder, 2016, pp. 13-345. Vidi takođe: Brent F. Nelsen, Alexander Stubb, The European Union: Readings on the Theory and Practice of European Integration, Lynne Rienner Publishers, Boulder, 2014.

${ }^{3}$ Ivona Lađevac, Međunarodnopravni subjektivitet Evropske unije, Institut za međunarodnu politiku i privredu, Beograd, 2016, str. 65.

${ }^{4}$ Tedros Adhanom Ghebreyesus, WHO Director-General's opening remarks at the media briefing on COVID-19, 11 March 2020, Internet: https://www.who.int/director-general /speeches/detail/who-director-general-s-opening-remarks-at-the-media-briefing-on-covid19--11-march-2020, 10/06/2021.
} 
čitavom svetu. Materijom i problematikom korona virusa i dalje se bavi veliki deo akademske zajednice, među kojima su i Henri Kisindžer, Bil Gejts, Juval Noa Harari, Džefri Saks, Frensis Fukujama, Džorž Soros, Noam Čomski, Džozef Štiglic, Ričard Has, Timoti Les, Jirgen Habermas, Boško Jakšić i mnogi drugi relevantni naučnici. U okviru akademskih debata, kao krucijalno, izdvojilo se pitanje projekcija mogućeg postpandemijskog sveta, čak i pre pronalska leka i vakcine protiv virusa.

Prema istraživanju novinara Džeremi Pejdža, Venksin Fana i Nataše Khan u „Vol Strit džornalu“ (Wall Street Journal) u SAD, 5. februara 2020. godine, kao nulta pacijentkinja navedena je 57-godišnja žena Vei Guišijan, prodavačica škampa sa pijace Huanan, u gradu Vuhanu u provinciji Hubei u Narodnoj Republici Kini. ${ }^{5}$ U saopštenju Dejli Mejlija (Daily Mail) u Ujedinjenom Kraljevstvu, ime nulte pacijentkinje Vei objavljeno je 26. marta 2020. godine. ${ }^{6}$ Prema kineskim izvorima, prvi pacijent zaražen korona virusom (čiji identitet nije objavljen) otkriven je 17. novembra 2019. godine. Prvi „Zvanični“ pacijent se pojavio 7. decembra 2019. godine, da bi 5. januara 2020. godine kineski zvaničnici objavili vest o otkriću novog soja korona virusa SARS KOV-2.

Kineski državni zvaničnici negiraju da je Vuhan prvi grad u kome se pojavio virusa SARS KOV-2 i da širenje epidemije potiče odatle. U vezi sa ovim, tim ljudi u misiji Svetske zdravstvene organizacije (SZO) kome je prvobitno zabranjen dolazak u Narodnu Republiku Kinu 5. januara 2021. godine, pa kasnije omogućen 14. januara do 10. februara 2021. godine, izvršio je istraživanje porekla i pojave korona virusa u Vuhanu. Posle uspešno obavljenog istraživanja, SZO tim je publikovao i dokument pod naslovom "Globalna studija porekla SARS-CoV-2 koju je sazvala SZO: Deo Kina". Nakon izveštaja u pisanoj formi, koji je ažuriran 6. aprila 2021. godine, najvažniji zaključak sadržan je u rednom broju 6 u kojem je, između ostalog, konstatovano da: „Nisu pronađeni dokazi o cirkulaciji SARS-KoV-2 među domaćom stokom, živinom i divljinom životinje pre i posle izbijanja SARS-KoV-2 u Kini." ${ }^{\prime 7}$

\footnotetext{
${ }^{5}$ Jeremy Page, Wenxin Fan, Natasha Khan, How It All Started: China's Early Coronavirus Missteps, Internet: https://www.wsj.com/articles/how-it-all-started-chinas-early-coronavirus-missteps-11583508932, 10/06/2021.

6 "The hunt for China's coronavirus 'patient zero': The first person to test positive in Wuhan's infamous food market was a woman selling live shrimps, leaked document reveals", Mail Online, 26 March 2020, Internet: https://www.dailymail.co.uk/news/article-8154933/Theperson-test-positive-Wuhans-market-woman-selling-live-shrimps.html, 10/06/2021.

7 "WHO-convened Global Study of Origins of SARS-CoV-2: China Part", Joint WHO-China Study, Geneva, 14 January-10 February 2021, p. 109. Tакође, objavljen je zajednički izveštaj
} 
Nesumnjivo, još od pojave korona virusa na važnom testu našao se, i još uvek jeste, zdravstveni sistem Evropske unije, koji po većini ovlašćenja nije centralizovan. Zapravo, najveći broj ovlašćenja po pitanju zdravstvenog sistema EU pripada državama članicama. Samim tim, korona virus i sprečavanje njenog širenja, od momenta pojave do danas, predstavlja jedan od najvećih izazova sa kojim se suočavaju zvaničnici Evropske unije u Briselu i Strazburu, ali i zvaničnici država koje su krenule putem evropskih intrgracija.

\section{Izazovi Evropske unije - od nemogućnosti donošenja Ustava do pandemije korona virusa}

Posle referendumskog neuspeha Ugovora o Ustavu za Evropu i Reformskog ugovora Evropske unije iz Lisabona, od 1. decembra 2009. godine, počeo je da se sprovodi potvrđeni Konsolidovani ugovor o Evropskoj uniji, kao nova osnova njenog pravnog sistema. ${ }^{8}$ Prema Ugovoru iz Lisabona, Evropska unija je dobila status pravnog lica u međunarodnim organizacijama, jedinstvenu spoljnu politiku i ubrzano proceduralno donošenje odluka u institucijama političkog sistema.

Među najvažnijim novinama, koje je doneo Lisabonski ugovor su: 1) utvrđivanje kvalifikovane većine u Savetu Evropske unije, 2) veća uloga Evropskog parlamenta u zakonodavanom procesu, 3) uvođenje funkcije predsednika Evropskog saveta, i 4) funkcija Visokog predstavnika Evropske unije za spoljnu politiku i bezbednost.

Sa stanovišta istorije trebalo bi pomenuti vanredni samit lidera Evropske unije od 9. novembra 2009. godine, kada je konsenzusom doneta odluka o

sa prilogom. "WHO-convened Global Study of Origins of SARS-CoV-2: China Part", Joint Report - ANNEXES, Geneva, 14 January-10 February 2021, pp. 3-193.

${ }^{8}$ Vidi o tome: Milutin Janjević (prir.), Reformski ugovor EU iz Lisabona, Službeni glasnik, Beograd, 2008. Aktom potpisivanja Lisabonskog sporazuma o reformama institucija Evropske unije, čiji je službeni naziv - Ugovor o izmenama i dopunama Ugovora o stvaranju Evropske unije (Mastrihtski ugovor) i Ugovora o stvaranju Evropske ekonomske zajednice (EEZ) (Rimski ugovor), 13. decembra 2007. godine, otvoren je međunarodni pravni proces za njegovo potvrđivanje od strane nadležnih zvaničnika država članica EU. Na satanku lidera EU u Briselu 29. oktobra 2009. godine, postignut je sporazum o Konsolidovanom ugovoru o Evropskoj uniji. Najzad, 3. novembra 2009. godine, ondašnji predsednik Češke republike - Vaclav Klaus stavio je zadnji potpis na ovaj važan evropski dokument. 
izboru belgijskog premijera Hermana van Rompeja na funkciju predsednika Saveta Evropske unije. Istom prilikom, Britanka i baronesa Ketrin Ešton izabrana je za visoku predstavnicu Evropske unije za spoljnu i bezbedonosnu politiku. ${ }^{9} \mathrm{To}$ je praktično omogućeno, na osnovu Ugovora iz Lisabona o izmeni Ugovora o Evropskoj uniji i Ugovora o osnivanju Evropske zajednice.

Predsednik Saveta Evropske unije bavi se pružanjem pomoći u dosezanju konsenzusa. Takođe, Predsednik Saveta Evropske unije predstavlja Evropsku uniju i na međunarodnim skupovima. Važno je napomenuti i to da šef diplomatije obavlja i funkciju potpredsednika Evropske komisije, ovlašćen je za međunarodno delovanje u ime Evropske unije, predsedava i sastancima ministara inostranih poslova punopravnih država članica, angažuje se i u radu Evropskog saveta, a ima i posebnu diplomatsku mrežu u svetu sa ljudima koji su njihovi diplomatski predstavnici. Najzad, predsednik Evropskog saveta, uz dogovor s liderima država punopravnih članica, utvrđuje glavne pravce spoljne politike Evropske unije, a koje će potom Visoki predstavnik sprovoditi u delo.

Sadašnja Evropska unija nalazi se pred izazovom globalnih promena, pogotovo posle BREGZIT-a od 24. juna 2016. godine i izlaska Ujedinjenog Kraljevstva Velike Britanije i Severne Irske iz Evropske unije, 31. decembra 2020. godine, posle 48 godina državnog punopravnoga članstva. ${ }^{10}$

\footnotetext{
${ }^{9} \mathrm{O}$ evropskim integracijama i diplomatiji vidi zapažene naučne radove: Jelica StefanovićŠtambuk, „Teorijski i istraživački problemi međunarodnih studija: slučajevi evropske integracije i diplomatije", Politička revija, Institut za političke studije, Broj 04/2008, Beograd, str. 1183-1208. U Evropskoj uniji je prema Jelici Stefanović Štambuk važna i bilateralna diplomatija. O bilateralnoj diplomatiji u Evropskoj uniji, vidi: Jelica Stefanović-Štambuk, „Bilateralna diplomatija u Evropskoj uniji“, Godišnjak Fakulteta političkih nauka, Broj 2/2008, Beograd, str. 323-353; Jelica Stefanović-Štambuk, „Evropska unija na putu ka objedinjujućoj diplomatiji“, Izazovi evropskih integracija, Službeni glasnik, Broj 8/2010, Beograd, str. 111-134.

${ }^{10}$ Sporazum o trgovini i saradnji između Evropske unije i Evropske zajednice za atomsku energiju, s jedne strane, i Ujedinjenog Kraljevstva Velike Britanije i Severne Irske, s druge strane, potpisan je prema najavi 30. decembra 2020. godine. Svoje potpise na pomenuti dokument su stavili od strane Evropske unije u Briselu predsednik Saveta Evropske unije, Šarl Mišel, i predsednica Evropske komije, Ursula fon der Lajen, a od strane Ujedinjenog Kraljevstva Velike Britanije i Severne Irske u Londonu, premijer Boris Džonson. „Primećujući da se Ujedinjeno Kraljevstvo povuklo iz Evropske unije i da je od 1. januara 2021. Ujedinjeno Kraljevstvo nezavisna priobalna država s korespondentnim pravima i obvezama po međunarodnom pravu...". "TRADE AND COOPERATION AGREEMENT BETWEEN THE
} 
Nedugo nakon neuspele konstitucionalizacije EU, usledio je i neuspešan pokušaj secesije Autonomne provincije Katalonije u Kraljevini Španiji. Najpre je bio sproveden nepriznati referendum od 1. oktobra 2017. godine o nezavisnosti u Autonomnoj pokrajini Kataloniji i ilegalnog proglašenja nezavisnosti Republike Katalonije 10. oktobra 2017. godine, sa potpisivanjem Deklaracije o nezavisnosti i suspenzija njene primene do kraja pregovora o mirnom razlazu sa državnim zvaničnicima u Madridu. Ipak, u slučaju ilegalnog proglašenja nezavisnosti Republike Katalonije, primenjena je Prodijeva doktrina od strane zvaničnika Evropske unije u Briselu. Prema relevantnoj anketi, koja je sprovedena u periodu od 30. aprila do 6. maja 2021. godine, 52 \% Katalonaca bilo je protiv nezavisnosti, a njih 47,2 \% bilo je za secesiju od Kraljevine Španije. ${ }^{11}$

Konačno, među aktuelnim izazovima sa kojima se savremena EU suočava, u kontekstu problema ovog istraživanja, kao ključni izaazovi se mogu izdvojiti: 1. pandemija SARS KOV-2 virusa i kašnjenja sa distribucijom medicinske opreme i vakcinacije ljudi u državama članicama koja se aktivno sprovodi do dosezanja kolektivnog imuniteta ljudi od najmanje 70\%, 2. migrantska kriza, 3. alternativa Evroazijske ekonomske unije i Novog puta svile - jedan pojas jedan put, 4. porast evroskepticizma i desničarskog ekstremizma u punopravnim državama članicama, 5. komplikovanost u funkcionisanju institucija političkog sistema Evropske unije, i 6. pitanja i problemi reforme Evropske unije. Kada imamo u fokusu aktuelnu pandemiju korona virusa, veoma su važni i dokumenti koji su usvajani ali i njihove praktične implementacije. Za države Zapadnog Balkana, nakon prijema Hrvatske u članstvo a u uslovima trajanja pandemije SARS COV-2, kao najznačajnije i ujedno aktuelno nameće se pitanje primene nove metodologije pregovora za pristupanje Evropskoj uniji i njena perspektiva.

\section{Kredibilna perspektiva Evropske unije za Zapadni Balkan}

Nakon široke javne rasprave, 5. februara 2020. godine u Briselu objavljen je dokument Evropske komisije: Unapređenje procesa pristupanja - kredibilna

EUROPEAN UNION AND THE EUROPEAN ATOMIC ENERGY COMMUNITY, OF THE ONE PART, AND THE UNITED KINGDOM OF GREAT BRITAIN AND NORTHERN IRELAND, OF THE OTHER PART", Official Journal of the European Union, Brussels, L 444/14, 31.12.2020, p. 20.

${ }^{11}$ Carles Castro, El rechazo a la independencia se eleva hasta el 52\% frente a un $42 \%$ que la apoya, Internet: https://www.lavanguardia.com/politica/20210516/7458735/rechazoindependencia-sube-52-frente-42-apoya.html, 10/06/2021. 
perspektiva Evropske unije za Zapadni Balkan. ${ }^{12}$ Nesumnjivo, zvaničnici Evropske unije opredeljeni su za „nedvosmislenu podršku evropskoj perspektivi Zapadnog Balkana. " ${ }^{13}$ Prema pomenutom dokumentu napredovanje bilo koje države kandidata vrednuje se prema zaslugama u procesu pridruživanja. ${ }^{14}$ "Osnovni cilj angažovanja Evropske unije na Zapadnom Balkanu je priprema države regiona da ispune sve zahteve koji proizlaze iz članstva. Ovo podrazumeva podršku suštinskim reformama u oblasti demokratije, vladavine prava i ekonomije i usklađivanje sa osnovnim evropskim vrednostima. To će zauzvrat podstaći stabilan i ubrzan privredni rast i socijalnu konvergenciju. " ${ }^{15}$ Veoma je važno za sve zvaničnike država kandidata da rade na transformaciji država regiona Zapadnog Balkana u funkcionalne tržišne ekonomije koje bi bile integrisane u jedinstveno tržište Evropske unije. Time bi se stvorila mogućnost za nova radna mesta u državama kandidata za punopravno članstvo u Evropsku uniju kao takvu. Ujedno, bilo bi omogućeno i preduzetništvo pod boljim poslovnim i investicionim uslovima, povećala bi se konkurentnost i životni standard ljudi, kao i većinsko sprečavanje masovnijeg odlaska mladih i obrazovanih ljudi. Kako je ekonomija Evropske unije i njenih država članica zabeležila pad uzrokovan pandemijom korona virusa, isti efekat zadesio je ekonomije država kandidata.

Za državu kandidata najvažniji element u procesu pristupanja Evropskoj uniji jeste uslovljavanje. Ostvareni napredak u procesu integracija nagrađuje se najpre bližom integracijom države kandidata sa Evropskom unijom i povećanjem finansijskih sredstava i investicija. ${ }^{16}$

Bliža integracija neke od država kandidata sa Evropskom unijom može se dosegnuti preko aranžmana za ubrzanu integraciju uz postepeno uvođenje pojedinačnih politika Evropske unije. Takođe, ubrzavanje integracije neke države kandidata u Evropsku uniju može se ostvariti i pristupanjem evropskom tržištu i raznim programima, kroz obezbeđivanje ravnopravnih uslova.

Što se tiče povećanja finansijskih sredstava i investicija kapitala, veoma je važno korišćenje Instrumenta pretpristupne pomoći, a preko kojeg države

\footnotetext{
12 "Enhancing the accession process - A credible EU perspective for the Western Balkans", European Commission, Brussels, COM(2020) 57 final, 5.2.2020.

${ }^{13}$ Ibidem, p. 1.

${ }^{14}$ Ibidem

${ }^{15}$ Ibidem, p. 2.

${ }^{16}$ Ibidem
} 
kandidati dobijaju donacije po zaslugama u sprovedenim reformama, kao i bliža saradnja sa međunarodnim finansijskim institucijama u interesu sticanja veće podrške.

Sa iskorišćavanjem namenskih finansijskih sredstava fodova Evropske unije države kandidati daju prednost Evropskoj uniji, ali i dopunskom spajanju sa Svetskom trgovinskom organizacijom. Najvažnija funkcija koju imaju fondovi Evropske unije jeste razvoj privrede država kandidata.

Pored nagrađivanja država kandidata Evropska komisija ima i mogućnost kažnjavanja za svaki ozbiljan propust ili stagnaciju u sprovođenju reformi i zahteva koje je neophodno ispuniti u procesu pristupanja. U kom stadijumu ostvarenih aktivnosti u procesu integracija u Evropsku uniju se nalazi država kandidat, objavljuje se u godišnjim izveštajima Evropske Komisije.

Tri problema se izdvajaju u odnosima zvaničnika Evropske unije sa zvaničnicima država kandidata.

1. Države, punopravne članice mogu odlučiti da otkažu pregovore u određenim oblastima, ili u najozbiljnijim slučajevima mogu ih i suspendovati u celini. Takođe, poglavlja koja su već zatvorena mogu se ponovo otvoriti u svrhu preispitivanja nekih pitanja.

2. Obim i intenzitet finansiranja iz fondova Evropske unije mogu se smanjiti, $s$ izuzetkom podrške civilnom društvu.

3. Prednosti bliže integracije, kao što je pristup programima Evropske unije i jednostrane koncesije za pristup zajedničkom tržištu, mogu se obustaviti ili u krajnjem slučaju i ukinuti.

Iz tog razloga veoma je važno informisanje ljudi u državama članicama i državama kandidatima o strateškim mogućnostima, ali i izazovima procesa proširenja Evropske unije i procesa pristupanja Uniji. Suštinska novina nove metodologije pregovora o pristupanju Evropskoj uniji odnosi se na uvođenje i sistematizovanje pregovaračkih poglavlja u tematske klastere. Sva poglavlja iz domena pravnog nasleđa (acquis communautaire) razvrstana su u šest klastera. Tom prilikom poglavlja 34 - „Institucije” ${ }^{17}$ i poglavlje 35 - „Ostala pitanja” ${ }^{18}$ ostala su da se razmatraju odvojeno.

\footnotetext{
${ }^{17}$ Ibidem, p. 6.

18 Ibidem
} 


\section{Tabela 1: Tehnički prilog i klasteri ${ }^{19}$}

Технички анекс: кластери (групе преговарачких поглавља)

\begin{tabular}{|c|c|}
\hline 1. Основе & $\begin{array}{l}23 \text { - Правосуђе и основна права } \\
24 \text { - Правда, слобода и безбедност } \\
\text { Економски критеријуми } \\
\text { Функционисање демократских } \\
\text { институција } \\
\text { Реформа јавне управе } \\
5 \text { - Јавне набавке } \\
18 \text { - Статистика } \\
32 \text { - Финансијска контрола }\end{array}$ \\
\hline 2. Унутрашње тржиште & $\begin{array}{l}1 \text { - Слободно кретање робе } \\
2 \text { - Слобода кретања радника } \\
3 \text { - Право пословног настањивања и } \\
\text { слобода пружања услуга } \\
4 \text { - Слободно кретање капитала } \\
6 \text { - Право привредних друштава } \\
7 \text { - Право интелектуалне својине } \\
8 \text { - Политика у области конкуренције } \\
9 \text { - Финансијске услуге } \\
28 \text { - Заштита потрошача и здравља }\end{array}$ \\
\hline 3. Конкурентност и инклузивни раст & $\begin{array}{l}10 \text { - Информационо друштво и медији } \\
16 \text { - Опорезивање } \\
17 \text { - Економска и монетарна политика } \\
19 \text { - Социјална политика и запошљавање } \\
20 \text { - Предузетништво и индустријска } \\
\text { политика } \\
25 \text { - Наука и истраживање } \\
26 \text { - Образовање и култура } \\
29 \text { - Царинска унија }\end{array}$ \\
\hline $\begin{array}{l}\text { 4. Зелена агенда и одржива } \\
\text { повезаност }\end{array}$ & $\begin{array}{l}14 \text { - Транспортна политика } \\
15 \text { - Енергетика } \\
21 \text { - Трансевропске мреже } \\
27 \text { - Животна средина и климатске } \\
\text { промене }\end{array}$ \\
\hline 5. Ресурси, пољопривреда и кохезија & $\begin{array}{l}11 \text { - Пољопривреда и рурални развој } \\
12 \text { - Безбедност хране, ветеринарска и } \\
\text { фитосанитарна политика } \\
13 \text { - Рибарство } \\
22 \text { - Регионална политика и } \\
\text { координација структурних инструмената } \\
33 \text { - Финансијске и буџетске одредбе }\end{array}$ \\
\hline 6. Спољни односи & $\begin{array}{l}30 \text { - Спољни односи } \\
31 \text { - Спољна, безбедносна и одбрамбена } \\
\text { политика }\end{array}$ \\
\hline
\end{tabular}

Izvor: Unapređenje procesa pristupanja - kredibilna perspektiva EU za Zapadni Balkan 
Države kandidati u regionu Zapadnog Balkana su: Republika Srbija, Republika Crna Gora koja je otvorila sva poglavlja, Republika Albanija i Republika Severna Makedonija. Status države kandidata za članstvo u EU u regionu trenutno nemaju Bosna i Hercegovina i Kosovo*. Republika Srbija je od 35 poglavlja otvorila njih 18, dok su dva privremeno zatvorena. Trebalo bi napomenuti da su poglavlja 23 i 24, kao i poglavlje 35 (koje se tiče tzv. Kosova), za Republiku Srbiju suspenzivna poglavlja u procesu pregovora, u skladu sa Novim pristupom pregovorima, promovisanim od strane EU nakon hrvatskog prijema u članstvo. ${ }^{20}$ Ovaj pristup nameće državama kandidatima obavezu da najpre otvore pregovaračka poglavlja 23 i 24, a da ih poslednja zatvore. Uslovljavanje svake države kandidata je takvo da i ukoliko su privremeno zatvorena, mogu se po potrebi preispitivanja ponovo otvoriti.

Nakon što je aktuelna predsednica Evropske komisije, Ursula fon der Lajen, u govoru o stanju Evropske unije, od 14. septembra 2020. godine, istakla da je Zapadni Balkan viđen kao deo Evrope, usledilo je objavljivanje plana za ekonomski oparavak regiona koji je potpomognut zelenom i digitalnom tranzicijom na Zapadnom Balkanu, a tiče se država kandidata i tzv. Kosova. ${ }^{21}$ Nedugo potom, Evropska komisija objavila je 6. oktobra 2020. godine još jedan važan dokument: Ekonomski i investicioni plan za Zapadni Balkan. ${ }^{22}$

Uticaj pandemije Kovid 19 prouzrokovao je velike poremećaje u ekonomijama država Zapadnog Balkana, uključujući i Kosovo*. Iz Instrumenta pretpristupne pomoći III (IPA III) za vremenski period od 2021. godine do 2027. godine, predviđeno je devet milijardi evra paketom ekonomske i finansijske pomoći Evropske unije. Inicijativa zvaničnika Evropske komisije bila je usmerena

${ }^{19}$ Ibidem, p. 7.

${ }^{20}$ ZAJEDNIČKA POZICIJA EVROPSKE UNIJE, U: KONFERENCIJA O PRISTUPANJU EVROPSKOJ UNIJI-SRBIJA, Brisel, 30. novembar 2015, str. 6. Politički i tehnički pregovori koji se vode u Briselu od 8. marta 2011. godine, između zvaničnika iz Beograda i Prištine trebalo bi da vode sveobuhvatnoj normalizaciji odnosa i Sveobuhvatnom pravno obavezujućem sporazumu između Kosova i Republike Srbije, što je zajednička pozicija Evropske unije za Poglavlje 35.

${ }^{21}$ State of the Union Address by President von der Leyen at the European Parliament Plenary, Internet: https://ec.europa.eu/commission/presscorner/detail/en/SPEECH_20_1655, 15/06/2021.

22 "An Economic and Investment Plan for the Western Balkans", European Commission, Brussels, $\operatorname{COM}(2020) 641$ final, 6.10.2020. 
na ekonomsku kovergenciju sa Evropskom unijom kroz investicije i podršku konkurentnosti, inkluzivnom rastu, održivoj povezanosti, kao i već pomenutoj zelenoj i digitalnoj tranziciji. S tim u vezi, predviđeno je i formiranje Garancijskog fonda za Zapadni Balkan koji bi obuhvatao davanje budžetskih garancija Evropske unije Evropskoj investicionoj banci u svrhu finansijskih operacija, i investicionih programa za ostvarivanje politika Evropske unije u delu IPA III pomenutog ekonomskog i investicionog plana u iznosu od maksimalno 20 milijardi evra. Naravno, za uspešnu primenu pomenutog plana važna je aktivna i uspešna primena dokumenta Evropske komisije Evropskog zelenog dogovora od 11. decembra 2019. godine. ${ }^{23}$

\section{Republika Srbija i mogućnost implementacije nove metodologije pregovora o pristupanju Evropskoj uniji}

S obzirom na to da je državama Zapadnog Balkana omogućeno da po novoj metodologiji pregovora pristupaju Evropskoj uniji, važno je ukazati na pojedine nepoznanice koje se tiču zvaničnika Republike Srbije. Kako je korona virus i u Republici Srbiji uzimao maha, predsednik Republike Srbije Aleksandar Vučić 15. marta 2020. godine, koristeći ovlašćenja predsednika po Ustavu Republike Srbije, proglasio je vanredno stanje u državi koje je trajalo do 6. maja 2020. godine. ${ }^{24} \mathrm{U}$ vezi s tim, preduzete su sve neophodne zdravstvene mere u cilju zdravstvene zaštite što većeg broja ljudi. ${ }^{25}$ Važan segment u očuvanju i funkcionisanju zdravstvenog sistema Srbije podrazumevao je optimalan i bezbedan rad ljudi. I u stručnoj javnosti prisutan je stav da se Republika Srbija nalazi među državama koje su napravile pakete različitih mera u cilju očuvanja privrednog razvoja i funkcionisanja privrede, kao i u cilju smanjenja negativnih posledica Kovida $19 .{ }^{26}$

23 "The European Green Deal", European Commission, Brussels, COM(2019) 640 final, 11.12.2019, pp. 2-24.

${ }^{24}$ Odluka o proglašenju vanrednog stanja, Dostupno: https://www.pravno-informacionisistem.rs/SIGlasnikPortal/eli/rep/sgrs/predsednik/odluka/2020/29/1/reg

${ }^{25}$ Prema statističkim podacima Instituta za javno zdravlje Srbije „Dr Milan Jovanović Batut“ iz Beograda, zaključno sa 15. junom 2021. godine do 15 časova, u Republici Srbiji ukupan broj registrovanih slučajeva zaraze ljudi korona virusom bio je 715,147, dok je broj smrtnih slučajeva je do iznosio 6,976, a procenat smrnosti 0,98\%.

${ }^{26}$ Sanja Jelisavac Trošić, Ana Jović Lazić, „Ekonomske posledice kovida 19 i mere podrške privredi Republike Srbije“, u: Zoran Jevtić, Mihajlo Kopanja (ur.), Zarazne bolesti kao globalni 
U ovom kontekstu važno je pomenuti iznos sredstava koji je izdvojen za program ekonomskih mera za podršku ovdašnjoj privredi. Program ekonomskih mera za podršku privredi Srbije i smanjivanje negativnih efekata prouzrokovanih pandemijom virusa Kovid 19, vredan je 5,2 milijarde evra. ${ }^{27}$

Uprkos početnim nedoumicama po pitanju mogućnosti primene nove metodologije pregovora, nedugo nakon objavljivanja iste, tačnije 9. jula 2020. godine, zvaničnici u Republici Srbiji prihvatili su da sprovode revidiranu metodologiju pregovora. Objašnjenje za ovakvu odluku delom leži i u stavu ministarke za evropske integracije u Vladi Republike Srbije, Jadranke Joksimović, da članstvo u Evropskoj uniji i nastavak procesa integracija i dalje predstavljaju najvažniji strateški cilj spoljne politike Republike Srbije. ${ }^{28}$ Ipak, u godišnjem Izveštaju Evropske komisije za Republiku Srbiju, od 6. oktobra 2020. godine, iznete su brojne primedbe u vezi nedovoljnog napretka u reformama po pitanju poglavlja 23 i 24, ali i potvrda uspešno izvršenih reformi u vezi ispunjavanja ekonomskih kriterijuma koje sprovodi Vlada Republike Srbije. U vezi s tim, nameće se zaključak da će celokupni tempo pregovora i dalje zavisiti prevashodno od dinamike reformi u domenu vladavine prava, ali i od normalizacije odnosa vlasti u Beogradu i Prištini. ${ }^{\text {"29 }}$

U svrhu uspešnog sprečavanja pandemije korona virusa, Evropska komisija je 8. aprila 2020. godine opredelila 800 miliona evra za Zapadni Balkan i Republiku Tursku. Od početka pandemije, Vladi Republike Srbije iz Evropske unije donirano je 17 miliona evra, zaključno sa 11. martom 2021. godine. Pri tome, iz Fonda solidarnosti Evropske unije za 2021. godinu, predviđeno je da budžet Vlade Republike Srbije dobije donaciju od 11.968.276 evra, za sprečavanje širenja pandemije korona virusa.

Komesar Evropske unije za susedstvo i proširenje, Oliver Varhelji (Olivér Várhely), predstavio je ambasadorima država članica revidiranu metodologiju

bezbednosni izazov pandemija covid-19: stvarnost i posledice, Univerzitet u Beogradu, Fakultet bezbednosti/Institut za međunarodnu politiku i privredu, Beograd, 2020, str. 106.

${ }^{27}$ Sanja Jelisavac Trošić, Ana Jović Lazić, „Ekonomske posledice kovida 19 i mere podrške privredi Republike Srbije“, op. cit., str. 106.

28 Jadranka Joksimović, „Novine u procesu pristupanja Republike Srbije EU“, Evropske novosti, Stalna konferencija gradova i opština, Beograd, Broj 1, avgust 2020, str. 6.

29 "Serbia 2020 Report", European Commission, Brussels, SWD(2020) 352 final, 6.10.2020, p. 3. 
za Republiku Srbiju i Republiku Crnu Goru, 17. marta 2021. godine u Briselu. Nedugo potom Vlada Republike Srbije na inicijativu Ministarke za evropske intigracije Jadranke Joksimović, 15. aprila 2021. godine donela je Odluku o formiranju Koordinacije za vođenje pregovora o pristupanju Republike Srbije Evropskoj uniji i i Tima za podršku pregovorima. ${ }^{30} \mathrm{Na}$ sastanku Saveta ministara Evropske unije održanog u Briselu 6. maja 2021. godine usvojen je i dokument Primena revidirane metodologije proširenja na pregovore o pristupanju sa Crnom Gorom i Srbijom. ${ }^{31}$ Konačno, Savet ministara Evropske unije usvojio je 11. maja 2021. godine revidiranu metodologiju za Republiku Crnu Goru i Republiku Srbiju. ${ }^{32}$ Kada je u pitanju Republika Srbija i mogućnosti primene nove metodologije pregovora, početna pretpostavka je bila da će prelazak na novu metodologiju povratiti kredibilitet procesu pregovora, ali i poverenje građana u sam proces evropskih integracija. No, ukoliko Srbija ne bude uspešno ispunjavala preuzete obaveze, mogućnost zahteva za suspenzijom pregovora od strane EK ili država članica i dalje ostaje na snazi. Ovo nije novina u odnosu na staru metodologiju, iako je način dolaženja do odluke o suspenziji prilično pojednostavljen i zasniva se na odlučivanju obrnutom većinom.

U suštini, najvažniji elementi revidirane metodologije za pristupanje Evropskoj uniji odnose se na veći fokus na najvažnije reforme u domenu vladavine prava, snažnije političko usmerenje, u funkciji poboljšanja procesa proširenja, veću dinamičnost procesa kroz grupisanje poglavlja u klastere, kako bi se ubrzale pripreme za integraciju i najzad unapređenje predvidljivosti kojim će se predstavljeni objektivni kriterijumi vrednovati pozitivnim i negativnim uslovljavanjima. ${ }^{33}$

lako je grupisanje poglavlja u šest klastera trebalo da doprinese dinamičnosti procesa, upitan ostaje način otvaranja samih klastera, što mnogi prepoznaju kao najveći izazov nove metodologije pregovora ka EU. Tim pre ovo važi za Srbiju, koja je otvorila 18 poglavlja koji se nalaze u različitim klasterima i podnela

\footnotetext{
30 Vidi: „Odluku o formiranju koordinacije za vođenje pregovora o pristupanju Republike Srbije Evropskoj uniji i tima za podršku pregovorima", Vlada Republike Srbije, Beograd, 05 broj 337-3422/2021-1.

31 "Application of the revised enlargement methodology to the accession negotiations with Montenegro and Serbia”, European Commission, Brussels, 8054/21 ELARG 19, 6 May 2021.

32 Ibidem, p. 3.

${ }^{33}$ Ibidem
} 
pregovaračke pozicije za još pet poglavlja. Na internoj debati zvaničnika Evropske komisije, održane u Briselu 11. juna 2021. godine, nije postignut konsenzus da se otvore klasteri 3 i 4, za koje su bili zainteresovani zvaničnici Republike Srbije. Protiv mogućnosti da se otvore pregovori po novoj metodologiji za klastere $3 \mathrm{i}$ 4, iz razloga nedovoljnog napretka u domenu vladavine prava, bili su zvaničnici Savezne Republike Nemačke, Kraljevine Holandije, Kraljevine Belgije, Velikog Vojvodstva Luksemburga, Kraljevine Danske, Kraljevine Švedske, Finske Republike, Republike Irske, Republike Hrvatske i Republike Bugarske. Ipak, nastavak rada na procesu integracija Republike Srbije u Evropsku uniju nastavio se kroz pripremu relevantnih aktera za održavanje političke eksplanatorne međuvladine konferencije 22. juna 2021. godine u Briselu.

\section{Zaključna razmatranja}

Integracija države kandidata u Evropsku uniju predstavlja složeno pitanje koje iziskuje angažman svih državnih zvaničnika i državne administracije. Dosadašnji tok pristupnih pregovora nije značajnije doprineo motivaciji državnih organa da ulože maksimalne napore za neophodne promene. $U$ tom smislu, prelazak na revidiranu metodologiju u 2021. godini, može biti nov podsticaj za bolje osmišljen i struktuiran pristup kako internim promenama tako i pregovorima sa Unijom. Ipak, uprkos uspešnoj promeni strukture u pregovorima Republike Srbije o pristupanju Uniji, činjenice pokazuju da još uvek nema očekivanog napretka po pitanju usklađivanja u poglavljima 23 i 24, kao i poglavlju 35. lako se političko vođstvo nametnulo kao lajtmotiv prelaska na novu metodologiju pregovara o pristupanju, ne može se osporiti nepovoljan uticaj koji je pandemija SARS COV-2 imala na čitavu politiku proširenja EU, pomerajući na agendi EU fokus sa ovog pitanja u stranu. Iz perspektive Republike Srbije, proces evropskih integracija je u svakom slučaju potrebno realnije sagledati, uz veće angažovanje državnih zvaničnika na ispunjavanju propisanih kriterijuma. Uspešan nastavak započetih opštih reformi moguć je samo uz političku stabilnost, ekonomski napredak, ali i dobre dobrosusedske odnose koji podrazumevaju uzajamno uvažavanje među državnim zvaničnicima na Zapadnom Balkanu. Kao posebno izazovno i ujedno zahtevno, nameće se pitanje normalizacije odnosa vlasti u Beograda i Prištini, u kontekstu poglavlja 35. Upravo u ovom domenu potreban je realno osmišljen i kvalitetan angažman državnih zvaničnika obeju strana. Tek nakon dosledno i uspešno i preduzetih mera na 
unutrašnjem planu, uz političku volju zvaničnika Republike Srbije i zvaničnika Brisela, moguće je govoriti o efektima nove metodologije pregovora.

\section{Literatura}

Nelsen, Brent F., Stubb, Alexander, The European Union: Readings on the Theory and Practice of European Integration, Lynne Rienner Publishers, Boulder, 2014.

Janjević, Milutin (prir.), Reformski ugovor EU iz Lisabona, Službeni glasnik, Beograd, 2008.

Janjević, Milutin (prir.), Ugovor o Ustavu za Evropu, Službeni glasnik, Beograd, 2005.

Jelisavac, Trošić, Sanja, Jović Lazić, Ana, „Ekonomske posledice kovida 19 i mere podrške privredi Republike Srbije", u: Zoran Jevtić, Mihajlo Kopanja (ur.), Zarazne bolesti kao globalni bezbednosni izazov pandemija covid-19: stvarnost i posledice, Univerzitet u Beogradu, Fakultet bezbednosti/Institut za međunarodnu politiku i privredu, Beograd, 2020.

Joksimović, Jadranka, „Novine u procesu pristupanja Republike Srbije EU“, Evropske novosti, Stalna konferencija gradova i opština, Beograd, Broj 1, avgust 2020.

Lađevac, Ivona, Međunarodnopravni subjektivitet Evropske unije, Institut za međunarodnu politiku i privredu, Beograd, 2016.

Olsen, Jonathan, McCormick, John, The European Union: Politics and Policies, Westview Press, Boulder, 2016.

Stefanović-Štambuk, Jelica, „Bilateralna diplomatija u Evropskoj uniji“, Godišnjak Fakulteta političkih nauka, Broj 2/2008, Beograd.

Stefanović-Štambuk, Jelica, „Teorijski i istraživački problemi međunarodnih studija: slučajevi evropske integracije i diplomatije“, Politička revija, Broj 04/2008, Institut za političke studije, Beograd.

Stefanović-Štambuk, Jelica, „Evropska unija na putu ka objedinjujućoj diplomatiji“, Izazovi evropskih integracija, Broj 8/2010 Službeni glasnik, Beograd.

Vukadinović, Radovan, Uvod u institucije i pravo Evropske unije, Pravni fakultet/Centar za pravo Evropske unije, Kragujevac, 2012. 


\title{
THE MAIN CHALLENGES OF THE NEW EU METHODOLOGY FOR ACCESSION NEGOTIATIONS IN THE CONTEXT OF THE SARS COV-2 PANDEMIC
}

\begin{abstract}
After the meeting of the Board of Commissioners of 5 February 2021, the European Commission officials have endorsed a new EU methodology of accession negotiations for the Western Balkans countries. The new methodology will directly apply as a revised accession process to the Republic of North Macedonia and the Republic of Albania. The Republic of Serbia and the Republic of Montenegro, having been allowed to declare on the new EU accession methodology, have both accepted the revised approach. The decision is yet to show its effects in the candidate states, on the citizens or the governing elites, respectively. The anticipated results concern stability, the rule of law, democracy, freedom and human rights, as well as economic development and social wellbeing. Undoubtedly, the greatest challenge to the successful implementation of the new EU methodology has been the SARS COV-2 pandemic. Besides the health challenge of the pandemic, other political and economic issues have been recognised, both for the EU member states and the candidates, including the establishment of a circular economy, reaching the goals proclaimed by the EU Green Plan, as well as the still unresolved status of Kosovo within the accession negotiations of the Republic of Serbia, etc.

This paper analyzes prospects and perspectives of the implementation of the new negotiation methodology, under the challenge of the SARS COV-2 pandemic, and the potential effect of the pandemic on Serbia's negotiation process. On the other hand, the European Union itself, as an international organisation sui generis, with its international legitimacy, faces the necessity of internal reform. The announced comeback of the European Union and the United States (US) to the Western Balkans will doubtlessly cause a reassessment and adjustment of the Republic of Serbia's government to new international challenges and the bilateral and multilateral circumstances of the relevant factors.
\end{abstract}

Keywords: European Union, Republic of Serbia, Western Balkans, SARS COV-2 pandemic, new methodology, accession. 